\title{
New records of lichens and allied fungi from Lapponia petsamoënsis, Murmansk Region, Russia
}

\author{
Gennadii Urbanavichus ${ }^{1} \&$ Irina Urbanavichene ${ }^{2}$ \\ ${ }^{1}$ Institute of North Industrial Ecology Problems, Kola Science Centre RAS, Akademgorodok 14a, Apatity, 184209 \\ Murmansk region, Russia. E-mail: g.urban@mail.ru \\ ${ }^{2}$ Komarov Botanical Institute RAS, Professor Popov Str. 2, 197376 St Petersburg, Russia. \\ E-mail: urbanavichene@gmail.com
}

\begin{abstract}
Fourteen species of lichens, four lichenicolous and two non-lichenized calicioid fungi are reported for the first time from the biogeographic province Lapponia petsamoënsis (NW Murmansk Region, Russia); of these, Buellia pulverea, Endococcus brachysporus and Micarea coppinsii are reported for the first time for Russia, Rosellinula haplospora is new to European Russia, and Aspicilia mashiginensis, Chaenothecopsis rubescens, C. vainioana, Lecidea sudetica, Micarea micrococca, Porpidia pachythallina, Protoparmelia atriseda and Psorotichia schaereri are new to the Murmansk Region. Brief notes, mainly on habitats and distribution, are provided for all species listed.
\end{abstract}

Keywords: Buellia pulverea, Endococcus brachysporus, Micarea coppinsii, Pasvik Nature Reserve, North-Western Russia

\section{INTRODUCTION}

The Pasvik Nature Reserve is located in the northwestern part of the Murmansk Region, in the biogeographic province Lapponia petsamoënsis on the east bank of the Paz River (Fig. 1) and has a land area of c. $117 \mathrm{~km}^{2}$ (http://www.pasvik-inari.net/neu/eng/area_Pasvik_Zapovednik.html; Urbanavichus \& Urbanavichene, 2017). Early lichenological exploration of the Lapponia petsamoënsis is connected with Finnish lichenologist Veli Räsänen, who published a detailed study on the lichens of Pechenga ("Petsamon jäkäläkasvisto"), listing more than 520 taxa (Räsänen, 1943). The most recent published additions to the Lapponia petsamoënsis lichen flora were from the Pasvik Reserve by, for example, Urbanavichus \& Fadeeva $(2017,2018)$ and Urbanavichus \& Urbanavichene (2017), and from other localities in Pechenga district by Konoreva et al. (2017). Among the 20 taxa listed here, the lichens Buellia pulverea and Micarea coppinsii and the lichenicolous fungus Endococcus brachysporus are reported for the first time for Russia, the lichenicolous fungus Rosellinula haplospora for European Russia, while the lichens Aspicilia mashiginensis, Lecidea sudetica, Micarea micrococca, Porpidia pachythallina, Protoparmelia atriseda and Psorotichia schaereri, as well as the non-lichenized calicioid fungi Chaenothecopsis rubescens and C. vainioana are new for the Murmansk Region. All reported taxa are new for the Lapponia petsamoënsis, the current number of lichens, lichenicolous fungi and allied fungi for this biogeographical province totaling c. 810 taxa.

This article is the completion of the project "The Lichen Flora of the Pasvik Nature Reserve (Murmansk Region, NW Russia)", which started in 2012 after the publication of the first list of lichens and allied non-lichenized fungi of Pasvik Reserve (Fadeeva et al., 2011); as a result, the known number of lichenized taxa for the Reserve is 520 , as well as 42 lichenicolous taxa and 15 saprobic fungi. This is $44 \%$ of the taxa known from the Murmanian lichen flora. As regards growth form, the Pasvik lichen flora is dominated by crustose (included non-lichenized) taxa, which comprise about two-thirds (370 taxa) of the studied taxonomic diversity.

\section{MATERIALS AND METHODS}

Lichen collections were made by the first author in August 2017 (except for Psorotichia schaereri which was collected in July 2014) mainly in pine forests and mountain tundra in the central part of the Pasvik Reserve. The material was microscopically studied and lichen substances analyzed by standard technique of thin-layer chromatography (TLC) in solvent systems A, B and C (Orange et al., 2001). Cited specimens are deposited in the Herbarium of the Institute of 


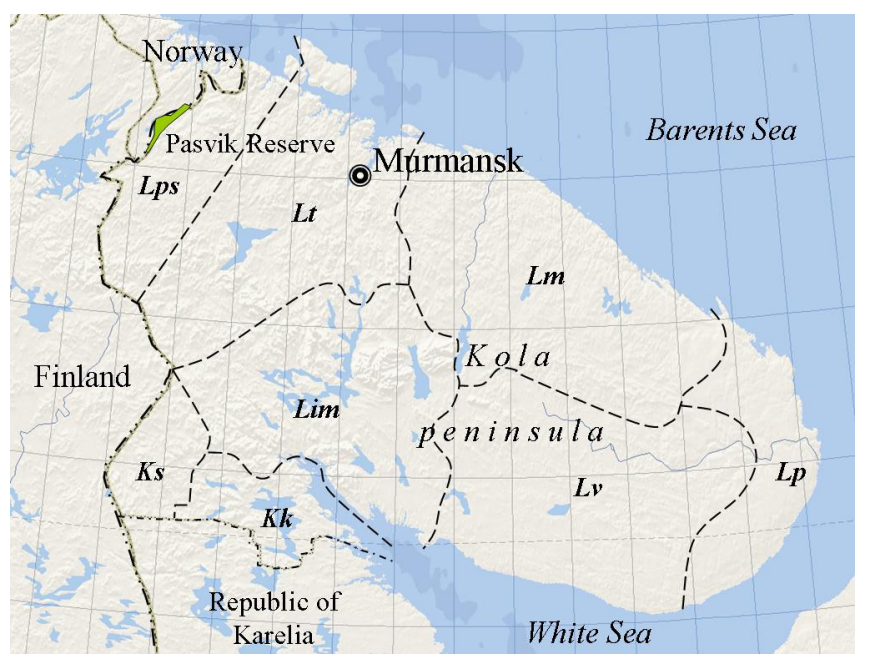

Fig. 1. Location of the Pasvik Reserve and the biogeographic provinces in the Murmansk Region. The abbreviations of the biogeographic provinces: Lps Lapponia petsamoënsis, Lt - Lapponia tulomensis, Lm - Lapponia murmanica, Lim - Lapponia imandrae, Lv - Lapponia varsugae, Lp - Lapponia ponojensis, Ks - Kuusamo (Regio kuusamoënsis), $\mathrm{Kk}$ - Karelia keretina. the North Industrial Ecology Problems (INEP). The nomenclature follows Santesson's Checklist (Nordin et al., 2011).

Studied localities (all in Murmansk Region, Pechenga district, Pasvik Reserve):

1. Central part of the reserve, north-eastern part of the Kalkupya Mt., rocky outcrops above the timberline, $69^{\circ} 18^{\prime} 13.2^{\prime \prime} \mathrm{N}, 2^{\circ} 23^{\prime} 16.5^{\prime} \mathrm{E}$, alt. c. 200-215 m, 22.08.2017.

2. Ibid., mountain-tundra belt, $69^{\circ} 18^{\prime} 05.4^{\prime \prime} \mathrm{N}$, $29^{\circ} 23^{\prime} 19.7$ "E, alt. c. 320 m, 22.08.2017.

3. Ibid., south-eastern part of the Kalkupya Mt., pine and birch forest-tundra, $69^{\circ} 17^{\prime} 18.6^{\prime \prime} \mathrm{N}$, $29^{\circ} 20^{\prime} 11.9^{\prime \prime E}$, alt. c. 280-300 m, 23.08.2017.

4. Ibid., $\mathrm{N}$ foot of the Kalkupya Mt., old-growth pine forest with old willow trees, $69^{\circ} 18^{\prime} 40.0^{\prime \prime} \mathrm{N}$, $29^{\circ} 24^{\prime} 19.0^{\prime \prime} \mathrm{E}$, alt. c. $75 \mathrm{~m}, 24.08 .2017$.

5. Ibid., $\mathrm{N}$ foot of the Kalkupya Mt., the east bank of the Paz River opposite to Nivasaari Island, oldgrowth pine forest, $69^{\circ} 18^{\prime} 47.4^{\prime \prime} \mathrm{N}, 2^{\circ} 22^{\prime} 45.0^{\prime \prime} \mathrm{E}$, alt. c. $55 \mathrm{~m}, 26.08 .2017$.

6. Ibid., S foot of the Kalkupya Mt., eastern shore of Lake Vouvatusjärvi, old-growth spruce forest, $69^{\circ} 16^{\prime} 19.3^{\prime \prime} \mathrm{N}, 29^{\circ} 18^{\prime} 28.8^{\prime} \mathrm{E}$, alt. c. $80 \mathrm{~m}$, 27.08.2017.

7. Northern part of the reserve, pine forest and calciferous rocks on the SW slope of the unnamed mountain, $69^{\circ} 20^{\prime} 56.8^{\prime \prime} \mathrm{N}, 2^{\circ} 46^{\prime} 33.2^{\prime \prime} \mathrm{E}$, alt. c. $130 \mathrm{~m}, 25.07 .2014$.
The following signs and abbreviations are used in the species list: ! - species new to Russia, !! - species new to Murmansk Region, \# - lichenicolous fungi, + - saprobic fungi, MR-Murmansk Region.

\section{THE SPECIES}

AsPICILIA GRISEA Arnold - 2: on rocks. The species was previously known in MR from Khibiny Mts and Lapponia imandrae (Urbanavichus et al., 2008). Formerly known in Russia only from MR and Komi Republic, North Ural Mts (Lavrinenko et al., 2005). Distribution in Fennoscandia: Sweden (Nordin et al., 2011). !!AsPicilia MASHIGINENSIS (Zahlbr.) Oxner - 2: on rocks. This rare species in Russia was previously known only from Novaya Zemlya (Andreev et al., 1996). Rather widespread in Norway and Sweden (Nordin et al., 2011).

!Buellia pulverea Coppins \& P. James - 6: on branches and trunk of spruce. This species is usually sterile (our specimens are without apothecia); thallus powdery sorediategranular, dull grey-green to brown-grey with distinct $\mathrm{Pd}+$ yellow, $\mathrm{C}+$ pink, $\mathrm{KC}+$ red reactions, and UV+ yellow due to the presence of alectorialic acid (TLC). B. pulverea is a rather widespread species in Central and Western Europe (e.g. Diederich et al., 1991; Coppins et al., 2009; Wirth et al., 2013) and surprisingly, it has not yet been reported from Northern Europe. When lacking apo- 
thecia, B. pulverea might be mistaken for the rather polymorph and widespread in Northern Europe species Pycnora sorophora (Vain.) Hafellner (also containing alectorialic acid), which is distinguished by the presence of usually numerous pycnidia and weakly convex areoles with apical soralia, $\mathrm{K}+$ yellow.

Chaenotheca ferruginea (Turner ex Sm.) Mig. - 5: on lignum of pine. This rare species in MR, previously known only from Lapponia imandrae and Karelia keretina (Urbanavichus et al., 2008). Common species in Fennoscandia (Nordin et al., 2011).

!!+ChAENotheCopsis RUBESCENS Vain. - 6: on bark of spruce. This is the northernmost locality in Europe. The nearest locality in NW Russia is the Pechero-Ilych Nature Reserve in Komi Republic (Hermansson et al., 2006). In Northern Europe known only from southern Finland (Nordin et al., 2011). The species is characterized by its non-septate spores, and the presence of a yellowish-red pigment which reacts $\mathrm{K}+$ persistent red.

!!+Chaenothecopsis vainioana (Nádv.) Tibell -4 : on bark of willow. Associated with Trentepohlia-containing Arthonia vinosa Leight. This is the northernmost locality in Europe. The nearest locality in NW Russia is the biogeographic province Karelia onegensis in Republic of Karelia (Fadeeva et al., 2007). Distribution in Fennoscandia: Norway, Sweden and Finland (Nordin et al., 2011).

!\#ENDOCOCCUS BRACHYSPORUS (Zopf) M. Brand \& Diederich - 3: on Porpidia melinodes (Körb.) Gowan \& Ahti (thallus) on rocks. The species differs from E. propinquus Nyl. by its small spores each with a $1.5 \mu \mathrm{m}$ thick septum (Sérusiaux et al, 1999). In Northern Europe known only from Sweden (Nordin et al., 2011).

LECANORA ANOPTA Nyl. - 2: on dry twigs of birch. This species in MR previously known only from Karelia keretina (Urbanavichus et al., 2008). It is characterized by its granular epihymenium, strongly inspersed hymenium with yellowish-brown grains and $\mathrm{N}^{+}$ reddish cinereorufa-green pigment (Wirth et al., 2013). Distribution in Fennoscandia: Norway, Sweden and Finland (Nordin et al., 2011).

Lecanora Cadubriae (A. Massal.) Hedl. - 6: on branches of spruce. Widespread in Northern
Europe. The species was previously known in MR from Lapponia murmanica, Lapponia imandrae, Khibiny Mts and Karelia keretina (Urbanavichus et al., 2008). A common species in Fennoscandia (Nordin et al., 2011).

LeCidea PROMISCENS Nyl. - 5: on rocks. This species in MR previously known only from Khibiny Mts and Lapponia varsugae (Urbanavichus et al., 2008). Distribution in Fennoscandia: only Finnmark in Norway and Sweden (Nordin et al., 2011).

!!LECIDEA SUdETICA Körb. - 5: on rocks. This rare species was previously known in NW Russia from Karelia kuusamoënsis and Karelia ladogensis in Republic of Karelia (Fadeeva et al., 2007). In Northern Europe known from southern Finland (Nordin et al., 2011). The species is a close relative of Lecidea lapicida (Ach.) Ach. var. pantherina Ach., but readily distinguished by its very thick (up to 1-1.5 $\mathrm{mm}$ ) thallus with large (1-3 $\mathrm{mm}$ diam.) strongly convex areoles, with 3-8 $\mu \mathrm{m}$ thick epinecral layer (Wirth et al., 2013).

!MiCAREA COPPINSII Tønsberg - 5: on rocks. This is the northernmost locality in Europe. In Northern Europe known only from southern and central Norway (Nordin et al., 2011). The species is characterized by its discrete, rounded, convex, grey-green areoles, bursting apically to produce soralia; soralia green with farinose soredia, some with blue-green $(\mathrm{K}-, \mathrm{N}+\mathrm{red})$ pigmented hyphae; prothallus not evident; photobiont cells 4-7 $\mu \mathrm{m}$ diam. (Coppins, 2009). Apothecia absent in our specimens. Thallus and soralia $\mathrm{C}+$ reddish, $\mathrm{KC}+\mathrm{red}, \mathrm{K}-, \mathrm{Pd}-, \mathrm{UV}-$; 5-O-methylhiasic acid [major], gyrophoric acid [trace], \pm lecanoric acid [trace] (TLC).

!!MicAREA MiCROCOCCA (Körb.) Gams ex Coppins - 4: on bark of willow. This is the northernmost locality in Europe. Rather widespread in southern Fennoscandia (Nordin et al., 2011). In NW European Russia known only from Leningrad Region (Konoreva \& Chesnokov, 2017). Our specimen is characterized by: thallus poorly developed, goniocysts coalescing, green; small apothecia, 0.1-0.2 $\mu \mathrm{m}$ diam., convex to hemispherical, cream white or brownish, K-, C-; ascospores 0-1 septate, oblong-ellipsoid or obovoid, 8.5-10.2 × 2.5-3.4 $\mu \mathrm{m}$ (lacking TLC due to small specimen). 
\#Muellerella ventosicola (Mudd) D. Hawksw. - 1: on Rhizocarpon geographicum (L.) DC. (thallus) on rocks. This species in MR previously known only from Lapponia ponojensis (Urbanavichus et al., 2008). Distribution in Fennoscandia: Norway and Sweden (Nordin et al., 2011).

!!PORPIDIA PACHYTHALLINA Fryday - 3: on small flat stones. Formerly known in Russia only from Komi Republic, "Yugyd Va" National Park, Ural Mts (UPS L-144956). New to Fennoscandia. The species is characterized by (1) thick thallus composed of dispersed, white, convex areoles, (2) tuberculate blue-grey soralia, (3) numerous small 'oil droplets' when viewed in section, (4) the presence of the confluentic acid (TLC), and (5) characteristic ecology, usually occurring on the upper surfaces of low, flat rocks at high altitude (Fryday, 2005). It is most likely to be confused with $P$. tuberculosa (Sm.) Hertel \& Knoph which is also sorediate and contains confuentic acid. However, $P$ pachythallina has a thicker, whitish thallus with a nonamyloid (I-) medulla.

!!PROTOPARMELIA ATRISEDA (Fr.) R. Sant. \& V. Wirth - 1: on rocks with Rhizocarpon sp. Formerly known in Russia from Leningrad Region and Southern Siberia (Zhdanov, 2011). Rather widespread in Norway, Sweden and Finland (Nordin et al., 2011).

!!Psorotichia schaERERI (A. Massal.) Arnold - 7: on calciferous rocks. This is the northernmost locality in Europe. The nearest locality in Fennoscandia is the province Lapponia kittilensis in northern Finland (Nordin et al., 2011) and in NW Russia is the biogeographic province Karelia onegensis in Republic of Karelia (Fadeeva et al., 2007). New genus to the Pasvik Reserve.

Rhizocarpon Cinereovirens (Müll. Arg.) Vain. - 1: on rocks. The species was previously reported in MR only from Khibiny Mts and Lapponia imandrae (Urbanavichus et al., 2008). Distribution in Fennoscandia: Sweden (Nordin et al., 2011).

!!\#Rosellinula haplospora (Th. Fr. \& Almq. ex Th. Fr.) R. Sant. - 5: on Aspicilia cinerea (L.) Körb. (thallus) on rocks. New to European Russia. This is the second report of this species for Russia; in Asiatic Russia, it has recently been reported from Zabaikal'skii
Territory (Zhurbenko \& Yakovchenko, 2014). Rather widespread in Norway and Sweden (Nordin et al., 2011). New genus to the Pasvik Reserve.

\#TAEniolella Rolfir Diederich \& Zhurb. - 1: on Cetraria nigricans Nyl. (thallus) on soil. Rather widespread in MR - Lapponia tulomensis, Lapponia murmanica, Lapponia imandrae, Khibiny Mts and Kuusamo (Urbanavichus et al., 2008). Distribution in Fennoscandia: Norway, Sweden and Finland (Nordin et al., 2011).

\section{ACKNOWLEDGEMENTS}

We are grateful to Natalia Polikarpova for organizing the expedition to the Pasvik Reserve, and to Prof. Mark Seaward who kindly corrected the English. This study was carried out in the framework of the State Research Programme of the Institute of North Industrial Ecology Problems KSC RAS (AAAA-A18-118021490070-5) and project "Herbarium collections of BIN RAS (history, conservation, investigation and replenishment)" of the Komarov Botanical Institute of the Russian Academy of Sciences (AAAAA18-118022090078-2).

\section{REFERENCES}

Andreev, M., Kotlov, Y. \& Makarova, I. 1996. Checklist of lichens and lichenicolous fungi of the Russian Arctic. The Bryologist 99: 137-169. https://doi. org/ $10.2307 / 3244545$

Coppins, B. J. 2009. Micarea Fr. (1825). In: Smith, C. W., Aptroot, A., Coppins, B. J., Fletcher, A., Gilbert, O. L., James, P. W. \& Wolseley, P. A. (eds). The lichens of Great Britain and Ireland. London, pp. 583-606.

Coppins, B. J., Scheidegger, C. \& Aptroot, A. 2009. Buellia De Not. (1846). In: Smith, C. W., Aptroot, A., Coppins, B. J., Fletcher, A., Gilbert, O. L., James, P. W. \& Wolseley, P. A. (eds). The lichens of Great Britain and Ireland. London, pp. 228-238.

Diederich, P., Sérusiaux, E. \& van den Boom, P. P. G. 1991. Lichens et champignons lichénicoles nouveaux ou intéressants pour la flore de la Belgique et des régions voisines. V. Lejeunia 136: 1-47.

Fadeeva, M. A., Dudoreva, T. A., Urbanavichus, G. P. \& Ahti, T. 2011. Lichens of the Pasvik Strict Nature Reserve (annotated checklist). Apatity. 80 pp. (In Russian).

Fadeeva, M. A., Golubkova, N. S., Vitikainen, O. \& Ahti, T. 2007. Conspectus of lichens and lichenicolous fungi of the Republic of Karelia. Petrozavodsk. 194 pp. (In Russian). 
Fryday, A. M. 2005. The genus Porpidia in northern and western Europe, with special emphasis on collections from the British Isles. Lichenologist 37: 1-35. https://doi.org/10.1017/S0024282904014628

Hermansson, J.-O., Pystina, T. N., Ove-Larsson, B. \& Zhurbenko, M. P. 2006. Lichens and Lichenicolous Fungi of the Pechoro-Ilychski Nature Reserve. Flora and Fauna of Nature Reserves 109: 1-79. (In Russian).

Konoreva, L. A. \& Chesnokov, S. V. 2017. Distribution in Russia some species of the genus Micarea Fr. In: Biodiversity: approaches of study and conservation. Proceedings of the International Scientific Conference dedicated to $100^{\text {th }}$ anniversary of the Department of Botany of Tver State University. Tver, pp. 169-172. (In Russian).

Konoreva, L. A., Frolov, I. V. \& Chesnokov, S. V. 2017. Lichens and allied fungi from the Pechenga district and surroundings (Lapponia petsamoënsis, Murmansk Region, Russia). Folia Cryptogamica Estonica 54: 17-23. https://doi.org/10.12697/ fce.2017.54.04

Lavrinenko, O. V., Plusnin, S. N., Urbanavichus, G. P. \& Urbanavichene, I. N. 2005. Lichens of the mountain-tundra zone in the Pechora-Ilych Reserve. Novitates Systematicae Plantarum Non Vascularum 38: 213-225. (In Russian, English summary).

Nordin, A., Moberg, R., Tønsberg, T., Vitikainen, O., Dalsätt, Å., Myrdal, M., Snitting, D. \& Ekman, S. 2011. Santesson's Checklist of Fennoscandian Lichen-forming and Lichenicolous Fungi. Ver. April 29, 2011 http://130.238.83.220/santesson/ home.php (1 February 2018).

Orange, A., James, P. W. \& White, F. J. 2001. Microchemical methods for the identification of lichens. London. $101 \mathrm{pp}$.
Räsänen, V. 1943. Petsamon jäkäläkasvisto. Annales Botanici Societatis Zoologicae-Botanicae Fennicae "Vanamo". 18(1): 1-110.

Sérusiaux, E., Diederich, P., Brand, A. M. \& van den Boom, P. P. G. 1999. New or interesting lichens and lichenicolous fungi from Belgium and Luxembourg VIII. Lejeunia 162: 1-95.

Urbanavichus, G. P. \& Fadeeva, M. A. 2017. Additions to the lichen flora of the Pasvik Reserve (Murmansk region) based on records of 2015-2016. Transactions of Karelian Research Centre of RAS. Ser. Biogeography 6: 61-69. (In Russian, English summary). https://doi.org/10.17076/bg581

Urbanavichus, G. P. \& Fadeeva, M. A. 2018. New records for lichen flora of Pasvik Reserve (Murmansk region). Uchenye zapiski Petrozavodskogo gosudarstvennogo universiteta 3: 104-110. (In Russian, English summary).

Urbanavichus, G. \& Urbanavichene, I. 2017. New records and noteworthy lichens and lichenicolous fungi from Pasvik Reserve, Murmansk Region, Russia. Folia Cryptogamica Estonica 54: 31-36. https:/ / doi.org/10.12697/fce.2017.54.06

Wirth, V., Hauck, M. \& Schultz, M. 2013. Die Flechten Deutschlands. Band 1. 672 pp.

Zhdanov, I. S. 2011. The genus Protoparmelia (Parmeliaceae) in Russia: key to the species. Novitates Systematicae Plantarum Non Vascularum 45: 159-167. (In Russian, English summary).

Zhurbenko, M. P. \& Yakovchenko, L. S. 2014. A new species, Sagediopsis vasilyevae, and other lichenicolous fungi from Zabaikal'skii Territory of Russia, southern Siberia. Folia Cryptogamica Estonica 51: 121-130. https://doi.org/10.12697/ fce.2014.51.14 
Folia Cryptog. Estonica 